\title{
A chimeric antigen receptor against prostate-specific membrane antigen, a tumor vasculature target
}

\author{
Stephen P Santoro*, Soorin Kim, Dimitrios Alatzoglou, Daniel J Powell, George Coukos \\ From Society for Immunotherapy of Cancer 28th Annual Meeting \\ National Harbor, MD, USA. 8-10 November 2013
}

The tumor endothelium plays a complex role in cancer development. Aberrant blood vessels provide structural support for the tumor, a barrier to immune infiltration, and also serve as a source of pro-tumorigenic signals. In accordance with their atypical function, surface protein expression on tumor vascular cells is distinct. This provides a unique opportunity for adoptive cell therapy. Prostate-specific membrane antigen (PSMA) is highly expressed in the vasculature of a variety of solid tumors, making it an attractive therapeutic target. We therefore designed a series of chimeric antigen receptors (CAR) against PSMA, utilizing an scFv derived from the antiPSMA antibody, J591. The scFv was linked to each of five intracellular signaling domains: Z, 28Z, BBZ, or 28BBZ. In vitro, we found that all CAR bearing $T$ cells performed equally well against endothelial targets. However, increased induction of the anti-apoptotic protein $\mathrm{Bcl}-\mathrm{xL}$ in $\mathrm{T}$ cells bearing the $28 \mathrm{BBZ}$ signaling domain led us to select the 28BBZ CAR for further study (herein known as P28BBZ). IFN $\gamma$ ELISA and Cr51 release assays confirmed the functionality of the P28BBZ CAR in vitro. To assess the ability of the P28BBZ T cells to recognize PSMA-positive vessels, human endothelial cells were seeded to a Matrigel basement membrane and allowed to form microvessels before co-culture with the CAR bearing $\mathrm{T}$ cells. Time-lapse microscopy revealed that the P28BBZ $\mathrm{T}$ cells preferentially homed to PSMApositive vessels, destroying them within 24 hours of coculture. In vivo, P28BBZ $\mathrm{T}$ cells were able to specifically and durably eliminate PSMA-positive hemangiomas. PSMA negative hemagiomas, which were injected on the opposite flank of the same mice, were unaffected by the

Ovarian Cancer Research Center, University of Pennsylvania, Philadelphia, PA, USA

Submit your next manuscript to BioMed Central and take full advantage of:

- Convenient online submission

- Thorough peer review

- No space constraints or color figure charges

- Immediate publication on acceptance

- Inclusion in PubMed, CAS, Scopus and Google Scholar

- Research which is freely available for redistribution 